\title{
Studying the intentions of hotel guests to engage in green programs in Egyptian hotels
}

\author{
Mohammed S. Sayed \\ Faculty of Tourism and Hotel Management, Helwan University, Egypt \\ mohammed.saber140@yahoo.com
}




\title{
Studying the intentions of hotel guests to engage in green programs in Egyptian hotels
}

\author{
Mohammed S. Sayed \\ Faculty of Tourism and Hotel Management, Helwan University, Egypt \\ mohammed.saber140@yahoo.com
}

Received: 25/5/2021 Revised: 5/6/2021 Accepted: 21/6/2021 DOI: https://doi.org/10.31559/IJHTS2020.2.1.6

\begin{abstract}
Many factors are currently pushing the hospitality sector to be more environmentally friendly. Moreover, hotel management is increasingly aware of its environmental impact, and it is gradually taking positive steps and green initiatives such as conserving water, energy-saving and solid waste reduction." Many hotels have already applied for some green plans. Besides, customers began to prefer green rather than regular hotels during their stay. This research aims to determine what influences the intention of hotel guests to participate in green activities.

Results have also shown that green hotel policies and practices are well accepted by tourists, such as energysaving light bulbs in guest rooms, recycling bins in rooms and lobbies, as well as green certifications. Many guests agreed to the green initiatives proposed in the study. They preferred to stay and participate in greenbased practices and programs in hotels unless this could increase accommodation costs. The result also provides hoteliers with how these attributes can attract holidaymakers who care about the environment. These programs require to be monitored continuously with the growth in the greening of hotels. Finally, hotel establishments must pay attention and start implementing some of these green initiatives because they are inexpensive and help protect our environment.
\end{abstract}

Keywords: Intentions; Guest; Hotel; Green programs; Egypt.

\section{Introduction}

All classes of society in different countries in the world are increasingly aware of the need to protect our natural resources to achieve sustainability and environmental protection practices for future generations (Honey, 2008). Tourism is undoubtedly the most important source of income and employment in many countries. Tourism depends on natural resources like beaches, forests, a warm climate, clean air, etc. Moreover, poorly managed tourism has a huge impact on the environment around the world, and while many businesses are ignoring these impacts, it will sooner or later be. The American Marketing Association attempts to manage the environmental impact of these unsustainable activities through green marketing that assumes that all products are considered to be environmentally safe, developing and marketing products designed to reduce the negative impact on the environment, and the production, promotion, packaging for the products must be sensitive or responsive to environmental attention (Kinoti, 2011)

Despite the hotel industry as one of the most important sectors in the tourism industry, it destroys the environment due to its high power, water, and non-durable product consumption (Noor et al., 2014, and Kasim, 2009). Nowadays, sustainability and environmentally friendly practices are becoming very important with a growing awareness of the need to protect our natural resources for future generations (Honey, 2008). Sloan et al. (2009) mentioned that investors, workers, and clients have higher expectations of the tourism industry toward responsible behavior focused on economic, social, and environmental factors. There are plenty of opportunities to improve pollution-free and sustainable business strategies, particularly in the tourism and hospitality sectors. However, many hotels are already adapting sustainable operating plans. 


\subsection{Green Hotel}

The hotel industry may not be the most polluting or resource-intensive industry on the planet. On the other hand, hotels consume large amounts of natural resources to provide convenient services/supplies (water, food, beverages, linens, lighting, air-conditioning, limousines, pools, and so on), causing direct or indirect ecological damage (Han et al., 2011). Through the concept of green hotels, the hotel industry is starting to reduce its impact on the environment. Green hotels refer to hotels that adopt environmentally friendly practices, such as saving water and energy, adopting eco-friendly purchasing policies, reducing emissions and waste disposal to protect the environment, and reducing operating costs (Green Hotel Association, 2008).

Nowadays, hotel guests are focusing more on environmentally friendly products, as well the hotel industry is becoming more aware of green hotel activities than before. Many green initiatives in sustainable development are being taken by hotel companies. Perhaps the most vital point for hotels is to understand customers' perceptions of these green practices. Hotels companies must determine whether customers will choose their hotels based on their green practices or whether management intends to implement green hotel programs. The hotel management should determine the tasks they will take in conserving the environment. Hotels can use this new trend to promote more environmentally friendly practices by surveying customers about their environmental concerns and identifying what influences their intentions to stay at green hotels or participate in their green programs.

\subsection{Green Hotel Practices}

For more sustainable development, the hotel industry has developed plans to reduce the negative impact on the environment such as waste and water recycling, towel reuse plans, linen control programs, eco-friendly restroom amenities, energy-saving lamps, and green certificates or certifications (Lee and Heo, 2009). Before making hotel purchases, travelers look for online hotel review sites (Kim et al., 2011). The negative impacts of hotels on the environment may influence some customers' choice of hotel or make it difficult to identify it as an environmentally friendly hotel. A green hotel can be described as a hotel that acts responsibly towards the community, society, local culture, and the whole surrounding environment (Jackson, 2010). Therefore, one hotel has policies for linen reuse and waste management, while another hotel may use series of steps to reduce energy consumption by using energy-saving devices in the lobby and guest rooms.

Despite these common environmental practices used in hotels, it is not easy for anyone to compare ecofriendly hotels. Green measures have been adopted through different certification measures to prevent confusion (e.g., Green Globe and Ecotel. A hotel that only engages in waste management activities is considered at the most basic level, while a hotel that applies more green practices is at the top level. There are many practices that hotels adopt to reduce environmental impact, hence it is essential to know which activities or features that consumer prefer during their stay in green hotels.

\section{Material and Methods}

\subsection{Data Collection}

To achieve the objectives of the study, a research model was developed to be more convenient and accurate for data analysis. Based on Verma and Chandra's (2016) and Deraman et al.'s (2015) studies, 15 items were selected to identify the main attributes influencing hotel guests' intentions to participate in their green programs. A series of amendments were made to the research, and the number of questions was reduced to obtain clear answers. The survey form consists of two parts. The first part is about determining how guests intended to engage in green activities in the hotel. The second part is related to green hotel programs and activities.

\subsection{Data Analysis}

Three major touristic areas with the fastest growing hotel accommodation in the Arab Republic of Egypt were selected for this study. Data were collected from 200 hotel guests from 4-star and 5-star hotels located in Cairo, Sharm El Sheik, and Hurghada. All quantitative data analysis was performed using a Statistical Package for the Social Sciences (SPSS, Version 23.0). Furthermore, means and frequencies for the selected hotel attributes were compared with demographic data. Variations in preferences were investigated based on age, gender, and educational levels. Pearson correlation analysis was used as it is a method for examining variations between group means.

\subsection{Results}

A total of 200 complete surveys were collected from the participants. Many respondents were men (66\%), and many of the participants were between the ages of 25-44 years old (35\%), while others were 15-24 (22\%), 45-64 (25\%), and (18\%) were over 60 years old. Most of them have education, as $39 \%$ stated they have a graduation degree, $20 \%$ have a master's degree, while $29.2 \%$ have a professional degree, and only $11.8 \%$ have a doctorate, as shown in Table 1. 
Table (1): Respondents Demographic Data

\begin{tabular}{|c|c|c|c|}
\hline & & $n$ & Percent \\
\hline \multicolumn{4}{|l|}{ Gender } \\
\hline Female & & 88 & 44 \\
\hline \multirow[t]{2}{*}{ Male } & & 132 & 66 \\
\hline & Total & 200 & 100 \\
\hline \multicolumn{4}{|l|}{ Age } \\
\hline 15 to 25 years & & 44 & 22 \\
\hline 26 to 45 years & & 70 & 35 \\
\hline 46 to 60 years & & 50 & 25 \\
\hline \multirow[t]{2}{*}{ over 60} & & 36 & 18 \\
\hline & Total & 200 & 100 \\
\hline \multicolumn{4}{|l|}{ Educational Level } \\
\hline Professional degree & & & 20 \\
\hline Graduation degree & & 85 & 39 \\
\hline Master & & 27 & 29.2 \\
\hline \multirow[t]{2}{*}{ Doctorate } & & & 11.8 \\
\hline & Total & 200 & 100 \\
\hline
\end{tabular}

\subsubsection{Intention to Engage in Green Activities}

As mentioned before, the main questionnaire form for the study is divided into two parts, and Table 2 shows the analysis of the 1st part, which concerns the intention of hotel guests to engage in green activities. Only Three items were selected and modified from the previous research. The Likert 5 -point scale ranges from $1=$ Strongly Disagree to $5=$ Strongly Agree used to predict guests' intention to participate in green activities. Table 2. displays the descriptive analysis of the study includes the mean score and standard deviation of the 1st part attributes.

Table (2): Intention to Engage in Green Activities.

\begin{tabular}{lccc}
\hline \multicolumn{1}{c}{ Item } & $\mathrm{N}$ & Mean & Std. Deviation \\
\hline I am willing to stay at a hotel that engages in green practices & 200 & 4 & 1.22 \\
I am willing to participate in the hotel's green activities. & 200 & 3.7 & 1.01 \\
I am willing to pay more to stay at a green hotel. & 200 & 2.4 & 1.12 \\
Valid N & 200 & & \\
\hline
\end{tabular}

The mean scores for this section ranged from 4 to 2.4. Table 2 shows that "I am willing to stay at a hotel that engages in green practices" is the highest mean score $(M=4, S D=1,22)$. Also, most of the participants had a positive intention to participate in green activities in hotels $(M=3.7, S D=1,01)$. Moreover, the result determines that most respondents were unlikely to pay extra for their stay at the green hotels $(M=2.4, S D=1,12)$. In general, the participants did not intend to pay more to stay in green hotels, and this may be if there were other options more suitable for them.

\subsubsection{Green Programs \& Activities}

Table 3 illustrates nine significant points selected from the previous studies regarding green hotel programs $\&$ activities. The Likert 5-point scale ranges from $1=$ Strongly Disagree to $5=$ Strongly Agree used to explain the participants' answers about some of the green activities and practices adopted by eco-friendly hotels.

Table (3): Green Programs \& Activities

\begin{tabular}{lccc}
\hline \multicolumn{1}{c}{ Item } & N & Mean & $\begin{array}{c}\text { Std. } \\
\text { Deviation }\end{array}$ \\
\hline Energy Efficient Light Bulbs in Guest & 200 & 4.1 & 1.21 \\
Green Certifications & 200 & 3.2 & 1.24 \\
Recycle Bins in the Guest Rooms & 200 & 4.8 & 1.01 \\
Recycle Bins in Hotel Lobby & 200 & 4.5 & 1.02 \\
Waste recycling policy & 200 & 3.8 & 1.22 \\
Sheet Changed Upon Request & 200 & 3.5 & 1.34 \\
Organic Food on the Menu & 200 & 3.3 & 1.45 \\
Towel Reuse Program & 200 & 3.4 & 1.40 \\
Refillable Shampoo Dispensers & 200 & 3.1 & 1.44 \\
Valid N & 200 & & \\
\hline
\end{tabular}


Amongst the programs and activities chosen, "Recycle Bins in the Guest Rooms" received the highest mean $(\mathrm{M}=4.8)$. This item was closely followed by "Recycle Bins in Hotel Lobby" (4.5) and "Energy Efficient Light Bulbs in Guest Rooms" ( $M=4.1)$. While "Refillable Shampoo Dispensers " received the lowest mean score $(M=3.1)$. Generally, it is clear to us that all participants agree with the programs and activities used in green hotels, but in some way. Table 2 displays the descriptive analysis of the study includes the mean score and standard deviation of the 2nd part attributes.

\subsubsection{Pearson Correlation Analysis}

The correlation should be greater than 0.3 to ensure that the independent variable has at least some relationship with the dependent variable. The correlation between the independent variable and the dependent variable, where the value was higher than 0.3 , is shown in Table 4 . Consequently, this issue proves that there is a positive correlation between green programs and activities that correlate with the guest's intention to participate. Indeed, these results agree with Deraman et al.'s (2015) study.

Table (4): Pearson correlation

\begin{tabular}{lcc}
\hline & Intention to Engage & Green programs \& activities \\
\hline Intention to Engage & 1 & $0.63^{*}$ \\
Green programs \& activities & $0.63^{*}$ & 1 \\
\hline
\end{tabular}

\section{Conclusions and Recommendations}

The main purpose of this study is to assess what influences hotel guests' intentions to participate in green programs while staying in the hotel (for example, towels reuse programs and using recycle bins in the guest rooms). This is not surprising given that previous research utilizing a similar measurement model observed that environmental concern was a notable predictor of intention to engage in green activities and even actual green behavior. Previous studies have shown that although the demand for green hotels has decreased, green is still a good advantage for hotels. Consequently, even if the traveler does not choose a property based upon the environmental performance, the guest will engage in the hotel's green initiatives. Consideration must be given to demand, competitors, and cost when pricing services in the hotel business. Before the hotel turns green and adjusts its room pricing strategy, it should also consider the potential benefits and costs. In addition, if hotel guests care about the environment, their willingness to participate in green practices will increase. Also, the study results may help hotels to shift and start using some green programs as a marketing tool and to preserve the environment.

Another key finding of this research is that green hotel activities are positively correlated with guests' willingness to participate. The results show that green hotel operators need to generate positive customer reviews and promote positive attitudes towards the green hotel to find good green facilities and services. It also suggested that hotel owners should expand their strategy to enhance their image by encouraging eco-friendly companies. These initiatives would be beneficial in increasing customers' strong desire to stay in a green hotel. As well as green hotel certification is a great tool that help to increase customer confidence in ecological products and services. Hotel companies should advertise their recognized eco-awards (such as ISO 14001) and keep their stakeholders updated on environmental results over time. Finally, the results of this research have listed some green activities that allow hotel promoters and developers to develop unique marketing strategies for attracting environmentally friendly customers. Besides, hotel marketers and planners with these new and unique descriptions will be able to gain the advantage of a new green hotel image.

\section{References}

1. Deraman, F., Abd Razak Abu Kassim, N. I., Arifin, A. I. M., \& Zaini, Z. M. M. (2015). The Intention of Hotel Guests' to Engage in Green Activities. J. Appl. Environ. Biol. Sci, 5(6S): 120-125.

2. Green hotel association. (2008). Available from: http://www.greenhotels.com/index.php\#a. [Cited 18 JUL 2020 ].

3. Han, H., Hsu, L. T. J., Lee, J. S., \& Sheu, C. (2011). Are lodging customers ready to go green? An examination of attitudes, demographics, and eco-friendly intentions. International journal of hospitality management, 30(2): 345-355, https://doi.org/10.1016/j.ijhm.2010.07.008

4. Honey, M. (2008). Ecotourism and sustainable development: Who owns paradise?. Island Press.

5. Jackson, A. E. (2010). Hotel guests' intentions to choose green hotels (Doctoral dissertation, University of South Carolina).

6. Kasim, A. (2009). Managerial attitudes towards environmental management among small and medium hotels in Kuala Lumpur. Journal of Sustainable Tourism, 17(6): 709-725, https://doi.org/10.1080/09669580902928468 
7. Kim, A. K., Airey, D., \& Szivas, E. (2011). The multiple assessment of interpretation effectiveness: Promoting visitors' environmental attitudes and behavior. Journal of Travel Research, 50(3): 321-334, https://doi.org/10.1177/0047287510362786.

8. Kinoti, M. W. (2011). Green marketing intervention strategies and sustainable development: A conceptual paper. International journal of business and social science, 2(23).

9. Lee, S., \& Heo, C. Y. (2009). Corporate social responsibility and customer satisfaction among the US publicly traded hotels and restaurants. International Journal of Hospitality Management, 28(4): 635-637, https://doi.org/10.1016/j.ijhm.2009.02.007.

10. Noor, N. A. M., Shaari, H., \& Kumar, D. (2014). Exploring tourist's intention to stay at green hotel: The influences of environmental attitudes and hotel attributes. The Macro theme Review, 3(7): 22-33.

11. Sloan, P., Legrand, W., Tooman, H., \& Fendt, J. (2009). Best practices in sustainability: German and Estonian hotels. In Advances in hospitality and leisure. Emerald Group Publishing Limited, https://doi.org/10.1108/s17453542(2009)0000005009.

12. Verma, V. K., \& Chandra, B. (2016). Hotel guest's perception and choice dynamics for green hotel attribute: A mixedmethod approach. Indian Journal of Science and Technology, 9(5), 1-9, https://doi.org/10.17485/ijst/2016/v9i5/77601. 